\section{Odarchenko D., Spodar K., Karbivnycha T., Sokolova E.}

\title{
CONDUCTING COMMODITY ASSESSMENT OF LACTOSE FREE AND ORDINARY (LACTOSE) YOGHURTS ON THE EXAMPLE OF UKRAINIAN PRODUCERS
}

The objects of research were 5 lactose-free and 5 ordinary (lactose) yoghurts presented on the market in Kharkiv (Ukraine). When carrying out research work, a complex of generally accepted chemical, physicochemical, mathematical methods was used, corrected for the merchandising evaluation of yoghurts.

The first stage of the study was to conduct a comparative organoleptic assessment of selected samples, paying attention to the uniformity of consistency, the presence of inclusions, the presence of foreign odors and flavors, as well as the uniformity of color.

According to the results of a comparative organoleptic quality assessment, it was found that all the studied samples of yoghurts had the same pure, sour milk taste, without extraneous odors unusual for the product, with a well-expressed sour taste. The results of the consistency assessment indicate that on the surface of sample No. 3 there was a separation of whey and a curd, with an undisturbed clot, which occurred due to the fact that lactosefree yoghurt was produced by the thermostatic method.

The second stage of the comparative merchandising assessment of selected yoghurt samples was to determine their main physical and chemical parameters in accordance with the requirements of DSTU 4343:2004 «Yoghurts. General technical requirements».

The analysis of the physicochemical indicators of the studied samples showed that only sample 1 had deviations from the requirements of the normative and technical documentation, namely, the content of the mass fraction of dry substances was lower by $0.3 \%$, which indicates non-compliance with the product manufacturing technology. The content of the mass fraction of dry substances of other samples was within acceptable limits.

When determining the content of titratable and active acidity, the mass fraction of fat in yoghurts, it was found that all the samples under study did not deviate from the requirements of the regulatory and technical documentation.

It was found that carrying out a commodity assessment (determination of organoleptic and physicochemical indicators) makes it possible to obtain a set of results on the freshness of the studied samples of lactose-free and ordinary (lactose) yoghurts.

Keywords: commodity assessment, lactose-free yoghurt, ordinary yoghurt, organoleptic and physico-chemical quality indicators.

Received date: 30.07 .2020

Accepted date: 24.09 .2020

Published date: 31.12 .2020
Copyright (C) 2020, Odarchenko D., Spodar K., Karbivnycha T., Sokolova E. This is an open access article under the CC BY license (http://creativecommons.org/licenses/by/4.0)

\section{Introduction}

Milk and dairy products are necessary to maintain human life, they are an important source of protein, vitamins and minerals, as well as calcium, are essential for public health [1]. One of the popular fermented milk products widely used in the diet of people in many countries of the world is yogurt [2]. Yoghurts have high medicinal, nutritional and dietary properties [3]. They are used for the treatment and prevention of inflammatory processes, diseases of the lungs and gastrointestinal tract [4]. Regular consumption of yoghurts increases the body's resistance to the development of pathogenic bacteria, infections, and oncological diseases, and also helps to increase immunity, reduce the body's intoxication [5]. Recently, the range of yoghurts has significantly expanded not only in terms of the mass fraction of fat, types of fillers, consistency, packaging, shelf life, but also in terms of lactose content: lactose-free, low-lactose and with a standard lactose content $[6,7]$. The most promising types of yoghurts are considered lactose-free and low-lactose, because lactose intolerance is very widespread in the world. It is estimated that $70-75 \%$ of the world's population suffers from lactase deficiency [8, 9]. The spread of this pathology, for example, in Ukraine is, depending on the region, 15-35\% of the adult population. For this category of people, it is necessary to develop special dairy products - lactose-free and low-lactose. A promising direction for the development of the dairy industry is the targeted production of exclusive varieties of yoghurts intended for people with lactose intolerance [10-12]. Today, assessing the quality of yoghurts is relevant, because sometimes, to reduce their 
cost, manufacturers can use low-quality raw materials, which are impossible, because yoghurts are consumed by sick people and children, and therefore they should in no way harm health.

Taking into account the urgency of this problem, the aim of research is to conduct a commodity assessment of lactose-free and conventional (lactose) yoghurts of various manufacturers using the example of Ukrainian manufacturers. The objects of the study were 5 lactose-free and 5 ordinary (lactose) yoghurts presented on the market in Kharkiv (Ukraine):

- sample No. 1 - «Latter for health». Lactose-free yoghurt. Manufacturer: Branch of «Sumy Dairy Plant» $\mathrm{SE}$ «Aromat»;

- sample No. 2 - «Latterforhealth» Yogurt «Greek style». Manufacturer: JSC «Chernhiv Milk Plant»;

- sample No. 3 - «Molokia» White lactose-free thick yogurt. Manufacturer: CJSC «Ternopil Dairy Plant»;

- sample No. 4 - «Na zdorovia». Lactose-free drinking yoghurt. Manufacturer: «Lustdorf»;

sample No. 5 - lactose-free yoghurt, TM «Yahotynske».

Manufacturer: JSC Yahotyn Butter Plant;

- sample No. 6 - «Traditional» yogurt, TM «Zarechye».

Manufacturer: PJSC «Kupyansk Milk Canning Plant»;

- sample No. 7 - sugar-free yoghurt, TM «Na zdorovia».

Manufacturer: Lustdorf firm;

- sample No. 8 - «Classic» yogurt, TM «Yahotynske».

Manufacturer: JSC Yahotyn Butter Plant;

- sample No. 9 - white drinking yogurt TM «Molokia».

Manufacturer: CJSC «Ternopil Dairy Plant»;

- sample No. 10 - «Carpathian» yogurt without sugar,

TM «Galychyna». Manufacturer: Galychyna Dairy Company LLC.

\section{Methods of research}

When performing research work, a set of generally accepted chemical, physicochemical, and mathematical methods was used, corrected for the assessment of lactose-free and conventional (lactose) yoghurts. Sampling was carried out in accordance with GOST 26809-86 «Milk and dairy products. Acceptance rules, sampling methods and sample preparation for analysis». The organoleptic characteristics of selected research samples were determined in accordance with DSTU 4343:2004 «Yoghurts. General technical conditions». The mass fraction of fat was determined in accordance with GOST 5867-90 «Milk and dairy products. Methods for the determination of fat». The mass fraction of dry fat-free substances was determined in accordance with GOST 3626-73 «Milk and dairy products. Methods for determination of moisture and dry matter». The titratable acidity was determined in accordance with GOST 3624-92 «Milk and dairy products. Titrimetric methods for determining acidity», active acidity - GOST 26781-85 «Milk. Methods for measuring $\mathrm{pH}$ ». Mathematical and statistical processing of the experimental results was carried out using a personal computer in MS Excel 2003.

\section{Research results and discussion}

The first stage of research was a comparative sensory evaluation of selected samples, which was determined in the laboratory at room temperature and sufficient lighting, without extraneous noise and drafts using the senses. After analyzing the requirements for the organoleptic characteristics of yoghurts, it was found that when assessing, one should pay attention to the consistency uniformity, the presence of inclusions, the presence of foreign odors and flavors, as well as the uniformity of color. The results of a comparative organoleptic assessment of the quality of the samples are shown in Table 1.

Tahle 1

Research results of the study of organoleptic indicators of the test samples

\begin{tabular}{|c|c|c|c|}
\hline Sample & Taste and odor & Consistency & Colour \\
\hline 1 & $\begin{array}{l}\text { Pure fermented milk, } \\
\text { without foreign tastes } \\
\text { and odors }\end{array}$ & $\begin{array}{l}\text { Homogeneous, gentle, } \\
\text { no gas formation }\end{array}$ & Milky white \\
\hline 2 & $\begin{array}{l}\text { Moderately pronounced, } \\
\text { pure fermented milk, } \\
\text { without foreign tastes } \\
\text { and odors }\end{array}$ & $\begin{array}{l}\text { On the surface there is } \\
\text { a stratification of whey } \\
\text { and a clot, with an un- } \\
\text { disturbed clot, without } \\
\text { gas formation }\end{array}$ & White \\
\hline 3 & $\begin{array}{l}\text { Moderately expressed } \\
\text { fermented milk, slightly } \\
\text { sour, without foreign } \\
\text { tastes and odors }\end{array}$ & $\begin{array}{l}\text { Homogeneous, gentle, } \\
\text { no gas formation }\end{array}$ & White \\
\hline 4 & $\begin{array}{l}\text { Pure, fermented milk, } \\
\text { without foreign tastes } \\
\text { and odors }\end{array}$ & $\begin{array}{l}\text { Homogeneous, gentle, } \\
\text { no gas formation }\end{array}$ & $\begin{array}{l}\text { White with } \\
\text { a yellowish } \\
\text { tinge }\end{array}$ \\
\hline 5 & $\begin{array}{l}\text { Pronounced fermented } \\
\text { milk, without foreign } \\
\text { tastes and odors }\end{array}$ & $\begin{array}{l}\text { Homogeneous, mod- } \\
\text { erately dense, without } \\
\text { gas formation }\end{array}$ & Milky white \\
\hline 6 & $\begin{array}{l}\text { Pronounced, pure } \\
\text { fermented milk, without } \\
\text { foreign tastes and odors }\end{array}$ & $\begin{array}{l}\text { Homogeneous, gentle, } \\
\text { no gas formation }\end{array}$ & Milky white \\
\hline 7 & $\begin{array}{l}\text { Moderately pronounced, } \\
\text { pure fermented milk, } \\
\text { without foreign tastes } \\
\text { and odors }\end{array}$ & $\begin{array}{l}\text { Homogeneous, mod- } \\
\text { erately dense, without } \\
\text { gas formation }\end{array}$ & $\begin{array}{l}\text { White with } \\
\text { a yellowish } \\
\text { tinge }\end{array}$ \\
\hline 8 & $\begin{array}{l}\text { Pure fermented milk, } \\
\text { slightly sour, without } \\
\text { foreign tastes and odors }\end{array}$ & $\begin{array}{l}\text { Homogeneous, mod- } \\
\text { erately dense, without } \\
\text { gas formation }\end{array}$ & White \\
\hline 9 & $\begin{array}{l}\text { Moderately expressed } \\
\text { fermented milk, slightly } \\
\text { sourish, without foreign } \\
\text { tastes and odors }\end{array}$ & $\begin{array}{l}\text { Homogeneous, gentle, } \\
\text { no gas formation }\end{array}$ & $\begin{array}{l}\text { White with } \\
\text { a yellowish } \\
\text { tinge }\end{array}$ \\
\hline 10 & $\begin{array}{l}\text { Pronounced fermented } \\
\text { milk, without foreign } \\
\text { tastes and odors }\end{array}$ & $\begin{array}{l}\text { Homogeneous, mode- } \\
\text { rately dense, without } \\
\text { gas formation }\end{array}$ & Milky white \\
\hline
\end{tabular}

According to the results of a comparative organoleptic quality assessment, it was found that all the studied samples of yoghurts had the same pure, sour milk taste, without extraneous odors unusual for the product, with a well-expressed sour taste. The results of the consistency assessment indicate that on the surface of sample No. 3 there was a separation of whey and a clot, with an undisturbed clot. This is due to the fact that the lactosefree yoghurt was produced in a thermostatic way. So, as a result of a comparative organoleptic quality assessment, it was found that all the studied samples fully meet the requirements DSTU 4343:2004 «Yoghurts. General technical conditions». The second stage of the comparative merchandising assessment of selected yoghurt samples was to determine their main physical and chemical parameters in accordance with the requirements of DSTU 4343:2004 «Yoghurts. General technical requirements», the results of the study are given in Table 2 . 
Results of the study of physicochemical indicators of the samples under study

\begin{tabular}{|c|c|c|c|c|}
\hline Sample & $\begin{array}{c}\text { Titratable } \\
\text { acidity, }{ }^{\circ} \mathrm{T}\end{array}$ & $\begin{array}{c}\text { Active } \\
\text { acidity }(\mathrm{pH})\end{array}$ & $\begin{array}{c}\text { Mass fraction } \\
\text { of fat, \% }\end{array}$ & $\begin{array}{c}\text { Mass fraction of } \\
\text { dry substances, \% }\end{array}$ \\
\hline 1 & 108 & 4.5 & 1.5 & 9.2 \\
\hline 2 & 95 & 4.65 & 2.5 & 9.66 \\
\hline 3 & 119 & 4.35 & 2.5 & 8.55 \\
\hline 4 & 109 & 4.5 & 1.5 & 9.67 \\
\hline 5 & 98 & 4.45 & 1.5 & 9.85 \\
\hline 6 & 97 & 4.65 & 1.0 & 9.75 \\
\hline 7 & 98 & 4.7 & 1.8 & 9.73 \\
\hline 8 & 93 & 4.65 & 1.5 & 9.62 \\
\hline 9 & 126 & 4.35 & 1.6 & 9.75 \\
\hline 10 & 107 & 4.75 & 2.2 & 9.7 \\
\hline
\end{tabular}

Titratable acidity is a criterion for assessing the freshness and naturalness of dairy products, and for yoghurts it is normalized in the range from 80 to $140^{\circ} \mathrm{T}$. The procedure for the analysis is specified in GOST 3624-92 «Milk and dairy products. Titrimetric Methods for Determining Acidity». At the same time, the range of values of this indicator in the studied samples had a significant scope. Comparing the research results, none of the yoghurt samples exceeds the norms of the normative and technical documentation. The highest acidity index was in sample No. $9-126^{\circ} \mathrm{T}$. This is explained by the fact that the shelf life of this yoghurt was running up to the end, which led to an increase in the acidity of the product. Sample No. 8 had a low acidity $-93^{\circ} \mathrm{T}$, other samples had an average acidity from $95{ }^{\circ} \mathrm{T}$ to $119{ }^{\circ} \mathrm{T}$, indicating the correctness of the technological process. For prototypes, an important indicator is the value of active acidity $(\mathrm{pH})$, by increasing which it is concluded that the yoghurt is ripe (readiness). The analysis procedure is specified in GOST 26781-85 «Milk. Methods for measuring $\mathrm{pH}$ ». As a result of the study, it was found that the range of active acidity in the studied samples had a significant range. Fluctuations in the $\mathrm{pH}$ value can be caused by a significant number of factors, in particular, the quality of milk used for yoghurt, the quantitative protein content in it, the nature of the fermentation process, etc. A significant increase in the $\mathrm{pH}$ value can be associated with the active development of the Bulgarian bacillus. Also, as a result of a comparative analysis, it was found that the active acidity of all studied samples of yoghurt did not exceed the permissible level according to DSTU 4343:2004 «Yoghurts. General technical requirements».

On the container of each test sample, the mass fraction of fat from $1.5 \%$ to $2.5 \%$ was indicated. The purpose of this experiment was to establish the compliance of the specified mass fraction of fat with the specified information on the consumer packaging of the samples. The analysis procedure is given in GOST 3624-92 «Milk and dairy products. Methods for the fat determination».

On each of the packages of the studied samples of package, the mass fraction of fat is indicated: on sample No. 1 $1.5 \%$, on sample No. $2-2.5 \%$, on sample No. 3 $2.5 \%$, on sample No. $4-1.5 \%$, on sample No. $5-1.5 \%$, on sample No. $6-1 \%$, on sample No. $7-1.8 \%$, on sample No. $8-1.5 \%$, on sample No. $9-1.6 \%$, on sam- ple No. $10-2.2 \%$. In the course of the experiment, the mass fraction of fat indicated on the labels was confirmed.

The solids of fermented milk drinks include all chemical constituents (fat, proteins, milk sugar, minerals, etc.), which remain in the product after moisture is removed from it.

The average dry matter content depends on the quality of the feedstock and its lactation time, and in most products it ranges from $8.6 \%$ (for low-fat fermented milk products) to $20 \%$ (for fortified and fatty foods). For classic types of lactic acid products, the main factors determining their quality are, first of all, proteins and fat among all components of the dry residue.

The procedure for determining the mass fraction of dry substances is specified in GOST 3626-73 «Milk and dairy products. Methods for determination of moisture and dry matter».

In accordance with the requirements of DSTU 4343:2004 «Yoghurts. General technical conditions» mass fraction of dry substances of yoghurts must be at least $9.5 \%$. As a result of the analysis, it was found that almost all samples meet the requirements of DSTU 4343:2004. Sample No. 1 had deviations by $0.3 \%$ of the mass fraction of dry matter, which indicates that the manufacturer did not follow the generally accepted technology for the production of yoghurts. Thus, among the presented samples in terms of the content of the mass fraction of dry substances, it is necessary to give preference to samples No. 2-10.

\section{Conclusions}

Indicators of the studied samples of yoghurts, it was found that all yoghurts had a pure, sour milk taste, without foreign odors unusual for the product, with a well-expressed sour taste. The consistency of all tested samples was homogeneous, delicate, without visible characteristics of gas formation. The analysis of physicochemical indicators of the samples under study showed that only sample No. 1 had deviations from the standards of DSTU 4343:004 «Yoghurts. General technical requirements», namely, the content of the mass fraction of dry substances was lower by $0.3 \%$, which indicates non-compliance with the manufacturing technology of the product. The content of the mass fraction of dry substances of other samples was within acceptable limits. By determining the content of titratable and active acidity, the mass fraction of fat in yoghurts, it was found that all the samples under study did not deviate from the requirements of the regulatory and technical documentation. It has been established that carrying out a commodity assessment makes it possible to obtain a set of results on the freshness of the studied samples of lactose-free and conventional (lactose) yoghurts. The obtained results are important for consumers and catering establishments, since yoghurt is the basis of a large number of sauces and dishes.

\section{References}

1. Hovorushko, T. A., Duda, V. P. (2013). Prodovolchyi rynok moloka Ukrainy, yoho rozvytok ta perspektyvy. Visnyk Odeskoho natsionalnoho universytetu, (18 (1/1)), 102-106.

2. Rozenberg, S., Body, J.-J., Bruyère, O., Bergmann, P., Brandi, M. L., Cooper, C. et. al. (2015). Effects of Dairy Products Consumption on Health: Benefits and Beliefs - A Commentary from the Belgian Bone Club and the European Society for Clinical and Economic Aspects of Osteoporosis, Osteoarthritis and Musculoskeletal Diseases. Calcified Tissue International, 98 (1), 1-17. doi: http://doi.org/10.1007/s00223-015-0062-x 
3. Dabija, A., Ropciuc, S. (2016). Aspects concerning obtaining innovative fermented dairy products. 16th International Multidisciplinary Scientific GeoConference SGEM 2016. Conference Proceedings, 185-192.

4. Ignatova, G. L., Blinova, E. V., Zakharova, I. A., Kochetkova, S. A., Revel-Muroz, N. P. (2018). Clinical efficacy of antiige therapy in adult patients with atopic severe uncontrolled asthma in real practice. Allergy: European Journal of Allergy and Clinical Immunology, Supplement, 73 (105), 671

5. Ponomarev, A. N., Melnikova, E. I., Bogdanova, E. V., Kharitonov, D. V. (2017). Impact of betalactoglobulin hydrolysate on structural and mechanical properties of allergenic potency-restricted yogurt. Foods and Raw Materials, 5 (1), 41-50. doi: http://doi.org/10.21179/2308-4057-2017-1-41-50

6. Anuarbekova, S., Dusenova, G., Sabyrkhan, A., Ermakhanova, A., Atabaeva, B. (2019). Bases for the development of lactose free dairy products. Journal of Agriculture and Environment, 1 (9), 12. doi: http://doi.org/10.23649/jae.2019.1.9.12

7. Jafarpour, D., Amirzadeh, A., Maleki, M., Mahmoudi, M. R. (2017). Comparison of physicochemical properties and general acceptance of flavored drinking yogurt containing date and fig syrups. Foods and Raw Materials, 5 (2), 36-43. doi: http:// doi.org/10.21603/2308-4057-2017-2-36-43

8. Delacour, H., Leduc, A., Louçano-Perdriat, A., Plantamura, J., Ceppa, F. (2017). Diagnosis of genetic predisposition for lactose intolerance by high resolution melting analysis. Annales de Biologie Clinique, 75 (1), 67-74. doi: http://doi.org/10.1684/ abc. 2016.1210

9. Corgneau, M., Scher, J., Ritie-Pertusa, L., Le, D. t. 1., Petit, J., Nikolova, Y. et. al. (2017). Recent advances on lactose intolerance: Tolerance thresholds and currently available answers. Critical Reviews in Food Science and Nutrition, 57 (15), $3344-$ 3356. doi: http://doi.org/10.1080/10408398.2015.1123671
10. Evdokimov, I., Bannikova, A. (2015). The scientific and practical principles of creating products with increased protein content. Foods and Raw Materials, 3 (2), 3-12. doi: http:// doi.org/10.12737/13114

11. Sukhikh, S., Astakhova, L., Golubcova, Y., Lukin, A., Prosekova, E., Milent`eva, I. et. al. (2019). Functional dairy products enriched with plant ingredients. Foods and Raw Materials, 7 (2), 428-438. doi: http://doi.org/10.21603/2308-4057-20192-428-438

12. Kondrasheva, N. N. (2020). Development of an innovative project for the new product launch. Components of Scientific and Technological Progress, 2 (44), 26-29.

Odarchenko Dmytro, Doctor of Technical Sciences, Professor, Head of Department of Commodity Science, Trade and Quality Management of Goods, Kharkiv State University of Food Technology and Trade, Kharkiv, Ukraine, ORCID: http://orcid.org/0000-0002-4792-3465

Spodar Kateryna, PhD, Associate Professor, Department of Commodity Science, Trade and Quality Management of Goods, Kharkiv State University of Food Technology and Trade, Kharkiv, Ukraine, ORCID: http://orcid.org/0000-0002-6799-7701

Karbionycha Tetiana, PhD, Associate Professor, Department of Commodity Science, Trade and Quality Management of Goods, Kharkiv State University of Food Technology and Trade, Kharkiv, Ukraine, ORCID: http://orcid.org/0000-0002-2238-5445

Sokolova Evgenia, PhD, Associate Professor, Department of Commodity Science, Trade and Quality Management of Goods, Kharkiv State University of Food Technology and Trade, Kharkiv, Ukraine, ORCID: http://orcid.org/0000-0002-6246-6012 